\title{
OBSERVATIONS OF A LABIDUS COECUS (LATREILLE) UNDERGROUND RAID IN THE CENTRAL HIGHLANDS OF COSTA RICA
}

\author{
By Ivette Perfecto
}

School of Natural Resources

University of Michigan

Ann Arbor, Michigan 48109

The predatory effect of army ants (subfamilies Dorylinae and Ecitoninae) on other arthropods has long been appreciated (Schneirla 1933, Williams 1941, Topoff 1969, 1984) and recently their effect more generally on ant communities has been noted (Franks \& Bossert 1983). Most direct observations of army ant attacks on other ant nests have been with above-ground raiders (Rettenmeyer 1963, Rettenmeyer et al. 1983). Observations of below ground raids, specifically noting particular species of other ants being attacked, are rare in the literature.

On 20 August 1991 an underground raid of Labidus coecus (Latreille) was observed on the grounds of the Centro de Investigaciones de Café, $10 \mathrm{KM}$ west of Barba de Heredia, Heredia Province, Costa Rica. The area was in a sparsely planted monoculture of coffee where I had been studying the ant community for two months. Observations of the raid encompassed a period of about 4.5 hours from 09:00 to 13:30, in an area in which all nests of Solenopsis geminata F., Dorymyrmex sp.(=Conomyrma), Pheidole sp., and Pheidole radoszkowskii Mayr had been previously located and marked. Underground activity of $L$. coecus was possible to monitor from the above ground activity of $S$. geminata, Dorymyrmex sp., and Pheidole sp. Brood was brought to the surface of the ground and transported elsewhere, to other nest holes in the case of Dorymyrmex sp. and to nearby leaf litter by Pheidole sp. and S. geminata. Curiously, of the five nests of Pheidole radoszkowskii in the general vicinity, none was observed with the above ground response to Labidus attack.

Manuscript received 31 July 1992 
At approximately 09:00 three colonies were noted to be under attack, a $S$. geminata colony, a Dorymyrmex sp. colony, and a Pheidole sp. colony. The first Dorymyrmex colony under attack brought brood across the surface of the ground to at least three other nests. At about 10:00, a second Pheidole sp. colony, located four meters from the first, came under attack. At 11:15 two other Dorymyrmex colonies were attacked, taking brood to nearby nests. A queen from one of these colonies was seen running with the workers from the attacked colony to one of the other nests across the surface of the ground. At 11:46, one of the nests to which the previous two colonies had escaped came under attack, the brood taken to a nest not yet used for brood deposition, including the removal of apparently the same queen that had earlier escaped attack.

At 12:04 an attack on a Dorymyrmex sp. colony some 6 meters from the site of the other attacks was noted as was an attack on another Pheidole sp. colony at 13:30. Another attack on a Dorymyrmex sp. colony in the original area was seen at 12:10. Finally an enormous attack on a large $S$. geminata colony was observed about 12:15, approximately 12 meters from the site of the original attacks. This nest was excavated to observe the thousands of $L$. coecus workers swarming throughout the $S$. geminata nest. Interestingly, no surface activity of any of the species was observed in the 12 meter intervening area.

I continued monitoring the area until 16:00, but found no evidence of further L. coecus attacks. Later in the day, at 12:30, $13: 45$, and 15:54, specific colonies that had been attacked were observed returning to the nest with brood.

A map indicating the approximate position of the nests under attack, the sequence of the attack, which Dorymyrmex sp. nests received brood from which other nests, and the position of all other nests in the general area is shown in figure 1.

The behavior patterns of the three species under attack were quite distinct. An attack on Dorymyrmex sp. was noticed by the presence of large number of pupae (inside cocoons) on the surface of the ground around the nest entrance, quickly followed by the moving of these and other brood to other nearby Dorymyrmex entrance holes, once to a nearby abandoned hole of a cicadelid larva. It was clear that the existence of so many "nests" in a small 

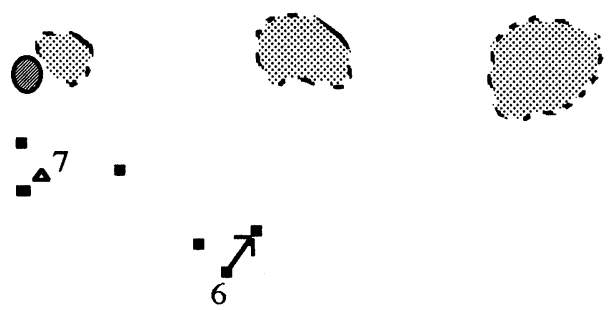

○
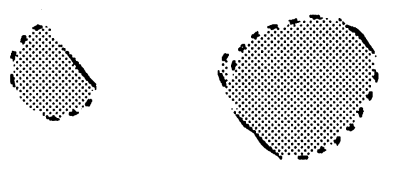

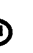

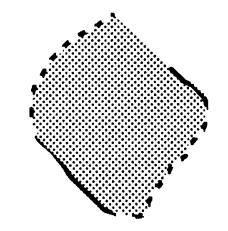

O. 0

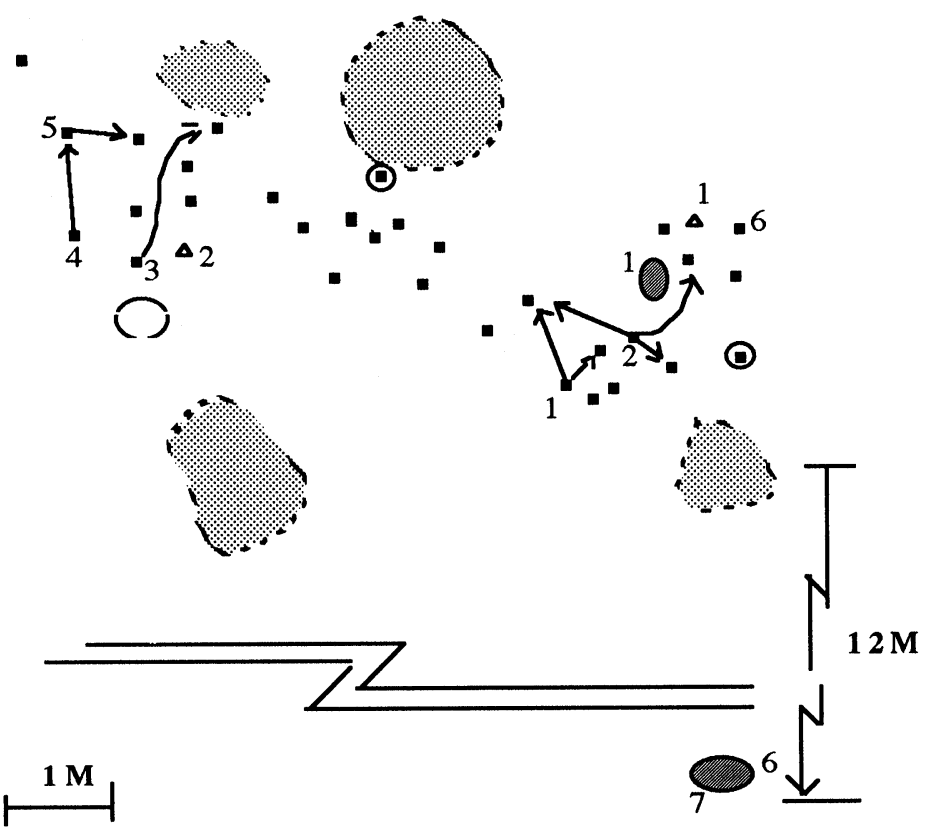


area provided refuge sites from attacking $L$. coecus. Indeed of 10 so-called nests excavated in the general vicinity of the attack, only two were found with queens and the rest had workers and brood only. The formation of this type of satellite colony has been reported for many ant species as a means to expand their foraging domain while maintaining contact through an exchange of foraging workers as well as the transport of immature forms back and forth (Higashi \& Yamauchi 1979, Yamauchi et al. 1987). However, Droual (1984) reported it as an anti-predator behavior in the ant Pheidole desertorum. Based on my observations, I propose that for Dorymyrmex sp., the formation of satellite colonies is also a mechanism to evade predation by army ants.

The three Pheidole sp. colonies observed under attack were seen to rapidly move brood out of the nest in many directions. Following the escaping ants revealed that the brood were being hidden in a variety of sites, under leaf matter and within rolled-up dry leaves. No Pheidole sp. colony was observed returning to the original nest site with brood. One excavated Pheidole sp. nest under attack revealed a relatively small number of $L$. coecus individuals, and no obvious attempt to defend the nest by majors under way.

A total of two $S$. geminata nests were observed under attack. The first was observed only from the surface. In it one could see $S$. geminata majors bringing dead $L$. coecus to the surface and discarding them. But the main behavior was moving brood away from the nest. The second $S$. geminata nest was rapidly excavated revealing a massive number of $L$. coecus, many engaged in combat with $S$. geminata majors, but most were simply moving rapidly in columns, apparently using the underground foraging trails previously established by $S$. geminata. The bulk of the $S$. geminata workers appeared to be engaged in taking brood away from the

Figure 1. Sketch of the area raided. Large shaded areas indicate approximate area of the canopy of individual coffee bushes. Small squares indicate Brachymyrmex sp. nest openings, open triangles those of Pheidole sp., circled squares those of Pheidole radoszkowskii, solid ovals those of living (shaded) and dead (unshaded) Solenopsis geminata. Arrows indicate nest openings from which and to which brood were taken by Dorymyrmex sp. Numbers indicate approximate times that each nest was raided $(1=09: 00,2=10: 00,3=11: 15,4=11: 30,5=11: 45,6=12: 00,7=$ 13:30). Note that the $S$. geminata nest at the bottom of the figure is about 12 meters from the concentration of the earlier part of the raid, and is included in the figure out of scale, as indicated by the jagged lines. The lower left scale indicator refers to the rest of the map. 
nest, rather than in any defensive behavior. Brood were taken to what appeared to be any site on the surface of the ground that offered even the slightest bit of cover.

The entire attack was completely subterranean, the only $L$. coecus observed on the surface being an occasional individual that appeared to be lost, not engaging in any obvious offensive behavior, or those individuals brought to the surface dead by $S$. geminata majors.

In the general area of the raid there were five nests of Pheidole radoszkowskii, none of which was observed under attack during the 4.5 hours of observation. This would suggest that $P$. radoszkowskii has some defense, perhaps chemical, that enables it to avoid the attacks of L. coecus, or perhaps that it is not energetically worth for $L$. coecus to prey on $P$. radoszkowskii.

Brachymyrmex musculus also occurs in the area and was evidently attacked by $L$. coecus. Since $B$. musculus's nests are very small and subterranean, they had not been previously mapped and the specific attack pattern on them was not carefully followed. It is obvious, nevertheless, that $B$. musculus also brought their brood to the surface and began hiding it in a variety of places, similar to Pheidole sp.

Of all the colonies attacked (including three Pheidole sp., two $S$. geminata, and numerous Dorymyrmex sp.), the following day provided evidence of mortality in only one of the attacked colonies. The smaller of the two $S$. geminata colonies was completely gone, and there was no evidence of a new colony anywhere nearby. The disappearance of this colony was verified by digging the nest the next morning after the raid. The nest of the second, larger S. geminata colony was physically reformed (it had been excavated the day before) and appeared to be significantly smaller than before the attack. All other colonies that had been in the area previously were evident and alive the day after the attack. A summary of all attacked nests and their fate is presented in table 1 .

These observations corroborate the speculations of Rettenmeyer (1963) that $L$. coecus is primarily an underground raider, and represent the first report of a raid that was completely subterranean. Furthermore, all previous reports of raids of this species bracket the time period from 19:45 to $08: 15$, effectively restricted to night time activity (Rettenmeyer 1963), while the raid reported herein 
Table 1. Attacked and unattacked ant colonies and their fate, resulting from the raid of Labidus coecus.

\begin{tabular}{lccc}
\hline Species & $\begin{array}{c}\text { Colonies } \\
\text { in area }\end{array}$ & $\begin{array}{c}\text { Colonies } \\
\text { attacked }\end{array}$ & $\begin{array}{c}\text { Colony mortality } \\
\text { (number killed) }\end{array}$ \\
\hline Dorymyrmex sp. & 27 & 18 & 0 \\
Pheidole radoszkowskii & 5 & 0 & 0 \\
Pheidole sp. & 3 & 3 & 0 \\
Solenopsis geminata & 3 & 2 & 1 \\
Brachymyrmex musculus & many & many & $?$ \\
\hline
\end{tabular}

occurred between 09:00 and 13:30. I speculate that, since the present raid was during the late morning and early afternoon hours, the previous concentration of observations during the night time hours may be because that is the only time raiding columns become epigaeic.

As noted above, $S$. geminata was the only species that actually lost a nest due to the raid. This species would appear to be especially vulnerable to subterranean raids due to its extensive network of subsurface trunk trails. In the area of observation, several $S$. geminata nests had been mapped with semi-surface covered trails extending over an area of more than $16 \mathrm{M}$ (Perfecto, unpublished manuscript). Such trunk trails offer obvious opportunities to the underground raids of $L$. coecus.

\section{ACKNOWLEDGEMENTS}

I thank Susy Remold, Stuart Ketcham and John Vandermeer for their help in the field, John Vandermeer for valuable comments on the manuscript, and the Coffee Institute (ICAFE) for allowing me to use their facilities. This research was possible with funding from an NSF grant to the author.

\section{SUMMARY}

An underground raid of the army ant Labidus coecus (Latreille) is reported in a coffee plantation in Costa Rica. Observations of the raid were made for a period of 4.5 hours during daylight. Underground activity of $L$. coecus was possible to monitor due to previous marking of nests of other ground-nesting ant species: Solenopsis geminata F, Dorymyrmex sp., Pheidole sp. and 
Pheidole radoszkowskii Mayr. The behavior of each of these species when under attack by $L$. coecus is described. Brood was brought to the surface and transported elsewhere by S. geminata, Dorymyrmex sp. and Pheidole sp. Dorymyrmex sp. transported the brood to other nests, suggesting the use of satellite colonies as anti-predator behavior. None of the $P$. radoszkowskii colonies located in the general area of the raid were observed under attack during the raid period.

\section{LiteratuRe Cited}

Franks, N. R. \& W. H. BosSERT

1983. The influence of swarm raiding army ants on the patchiness and diversity of a tropical leaf litter ant community. In E. L. Sutton, T. C. Whitmore, and A. C. Chadwick, eds., Tropical Rain Forest: Ecology and Management, pp. 151-163. Blackwell, Oxford.

Droual, R.

1984. Anti-predator behaviour in the ant Pheidole desertorum: the importance of multiple nests. Animal Behaviour 32(4): 1054-1058.

Higashi, S. \& K. YAMAUCHI

1979. Influence of a supercolonial ant Formica (Formica) yessensis Forel on the distribution of other ants in Ishikari Coast. Japanese Journal of Ecology, 29(3): 257-264.

TOPOFF, H. R.

1969. A unique predatory association between carabid beetles of the genus Helluomorphoides and colonies of the army ant Neivamyrmex nigrescens. Psyche, 76: 375-381.

1984. Social organization of raiding and emigrations in army ants. Advances in the Study of Behavior, 14: 81-126.

ReTtenMeyer, C. W.

1963. Behavioral studies of army ants. University of Kansas Science Bulletin, 44: $281-465$.

Rettenmeyer, C. W., R. Chadab-Crepet, M. G. Naumann, and L. Morales

1983. Comparative foraging by Neotropical army ants. In P. Jaisson, ed., Social Insects in the Tropics, vol 2, pp. 59-73. Université Paris-Nord, Paris.

SChNeIrla, T. C.

1933. Studies on army ants in Panama. Journal of Comparative Psychology, 15: $267-299$.

WiLLIAMS, E. C.

1941. An ecological study of the floor fauna of the Panama rain forest. Bulletin of the Chicago Academy of Science, 6: 63-124.

Yamauchi, K., Y. ITõ, K. Kinomura, and H. TAKamina

1987. Polycalic colonies of the weaver ant Polyrhachis dives. Kontyu, Tokyo, 55(3): 410-420. 

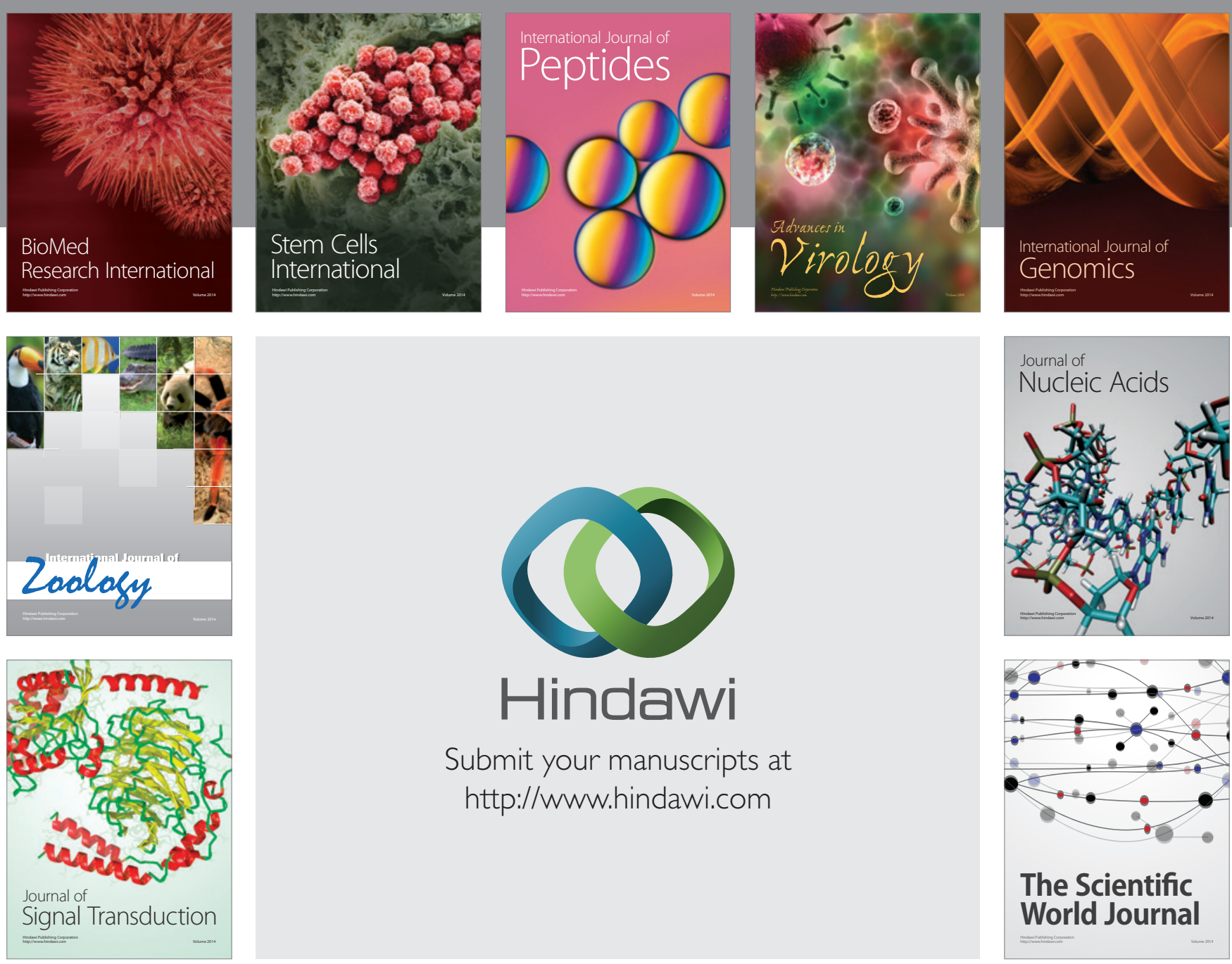

Submit your manuscripts at

http://www.hindawi.com
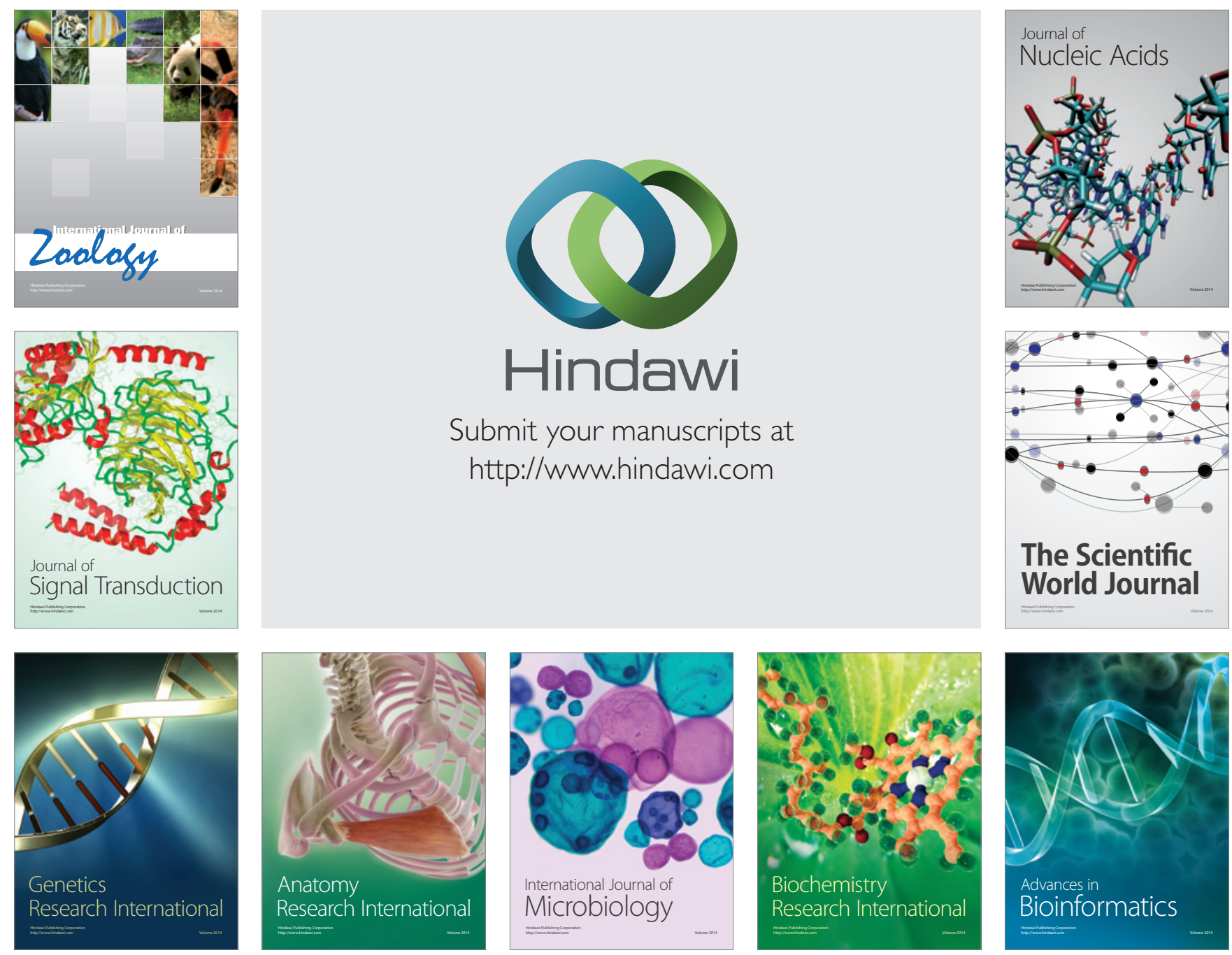

The Scientific World Journal
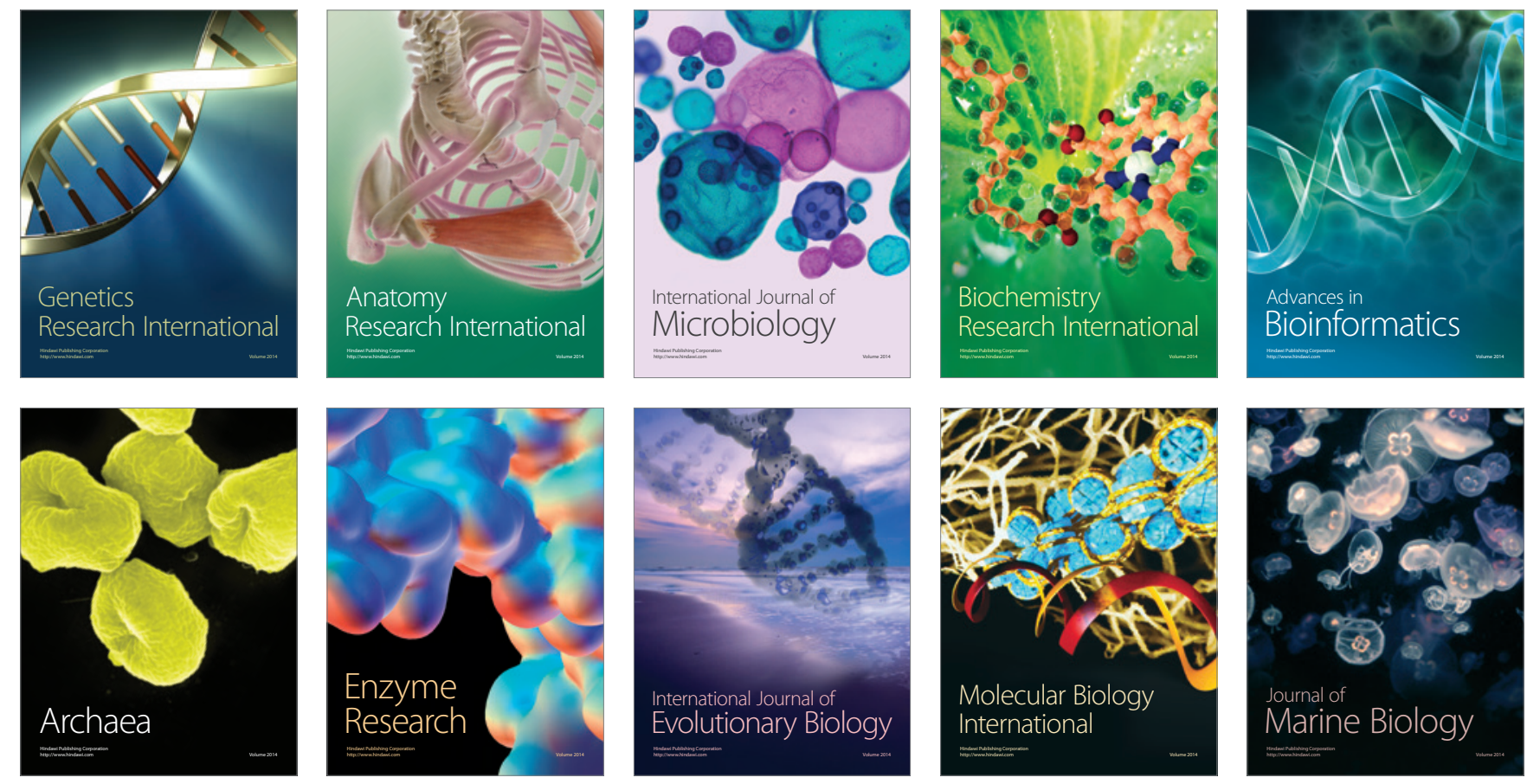